\title{
Usability Test:
}

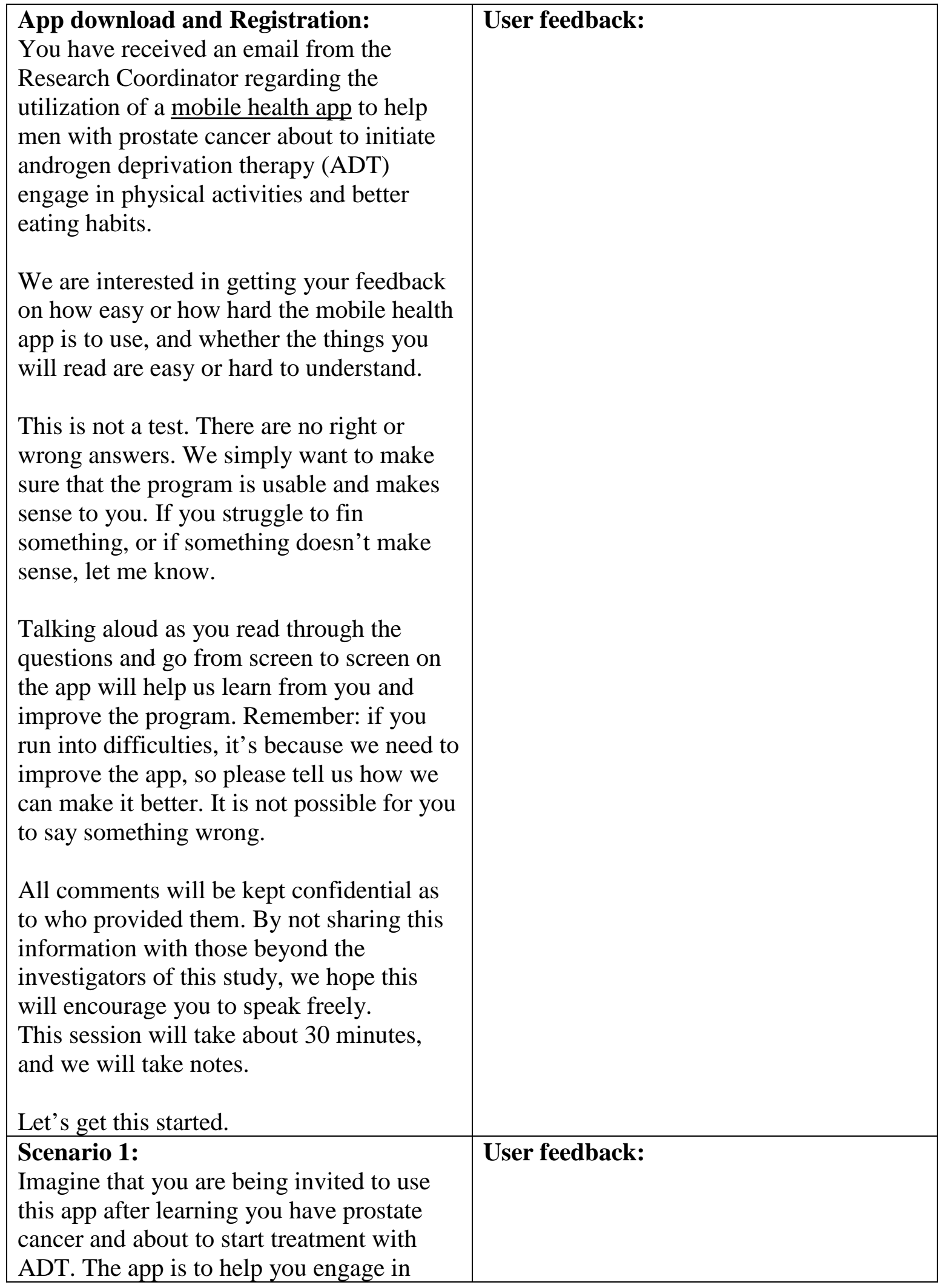




\begin{tabular}{|c|c|}
\hline $\begin{array}{l}\text { more physical activities in your weekly } \\
\text { routine and to help you develop better } \\
\text { eating habits. }\end{array}$ & \\
\hline $\begin{array}{l}\text { First you will receive the following email } \\
\text { requesting you to register via our online } \\
\text { server. Please read through the email and } \\
\text { talk us through what you would do next } \\
\text { after receiving this email, including } \\
\text { whether you find the instructions well- } \\
\text { described, and easy to follow. }\end{array}$ & \\
\hline $\begin{array}{l}\text { Then please go on to search for the app and } \\
\text { downloading it based on the instructions } \\
\text { provided within that email, and let me } \\
\text { know if you run into any trouble with that } \\
\text { part. }\end{array}$ & \\
\hline $\begin{array}{l}\text { As the app is downloaded, please register } \\
\text { as you would based on the instructions } \\
\text { provided within that email, and let me } \\
\text { know if you run into any trouble or if there } \\
\text { is anything that is hard to understand. }\end{array}$ & \\
\hline $\begin{array}{l}\text { Scenario 2: } \\
\text { Next, the app will ask you what typical } \\
\text { physical activities you will engage in } \\
\text { during the week. What do you do next? } \\
\text { Is it clear from the screen that you may } \\
\text { change these options any time? } \\
\text { Are you able to find the types of physical } \\
\text { activities you engage in from the provided } \\
\text { list? }\end{array}$ & User feedback: \\
\hline $\begin{array}{l}\text { Feel free to continue talking out these } \\
\text { questions and answer choices, and to give } \\
\text { us your thoughts. }\end{array}$ & \\
\hline $\begin{array}{l}\text { Scenario 3: } \\
\text { As you are taken to the home screen of the } \\
\text { app, please familiarize yourself with the } \\
\text { various facets of the app, such as the } \\
\text { exercise activities tab, and the food log tab. } \\
\text { How easy is it to navigate from one facet to } \\
\text { another? Is navigation within the app } \\
\text { intuitive? }\end{array}$ & User feedback: \\
\hline Scenario 4: & User feedback: \\
\hline
\end{tabular}




\begin{tabular}{|c|c|}
\hline $\begin{array}{l}\text { Now please go to the exercise activities tab } \\
\text { and pretend to log two of any activities } \\
\text { from the options you have chosen. } \\
\text { How easy do you find logging exercise to } \\
\text { be? } \\
\text { Did you realize that you can log exercise } \\
\text { for the previous day? }\end{array}$ & \\
\hline $\begin{array}{l}\text { Scenario 5: } \\
\text { Now pretend that you want to record the } \\
\text { food you ate. } \\
\text { Is it obvious that you can take a picture of } \\
\text { the food, but that you can also select a } \\
\text { previously taken picture from your camera } \\
\text { roll? } \\
\text { What do you think of the food-rating } \\
\text { process? Is the process intuitive? } \\
\text { Did you realize that you can record food } \\
\text { you ate previously? }\end{array}$ & User feedback: \\
\hline $\begin{array}{l}\text { Scenario 6: } \\
\text { Please familiarize yourself with the } \\
\text { graphics of the exercise and food tabs. Is it } \\
\text { easy or difficult to understand the graphics? } \\
\text { Do you think anything can be improved? }\end{array}$ & User feedback: \\
\hline $\begin{array}{l}\text { Wrap-up: } \\
\text { Thank you for working your way through } \\
\text { the app, and helping us identify areas } \\
\text { where we can improve it. } \\
\text { In closing, would you please tell us what } \\
\text { you liked best about the mobile health app? } \\
\text { And least? }\end{array}$ & User feedback: \\
\hline $\begin{array}{l}\text { What do you think was the main purpose of } \\
\text { the app? }\end{array}$ & \\
\hline $\begin{array}{l}\text { Do you think the app will be helpful for } \\
\text { men with prostate cancer? }\end{array}$ & \\
\hline $\begin{array}{l}\text { Do you have any other feedback or } \\
\text { suggestions that would help us improve the } \\
\text { questionnaire or your experience with it? }\end{array}$ & \\
\hline Thank you for your time. & \\
\hline
\end{tabular}

